\title{
The Development Study of Madura Area (An Area Marketing Approach)
}

\author{
Muchammad Nurif ${ }^{1}$ Hermanto $^{2}$
}

\begin{abstract}
The development of Madura area has its own challenge due to its low development indicators which become the complexity barometer of development problems in this area. The development of Madura area has main obstacles, such as the limitation of infrastructure and transportation acces from and to Madura that weakens the economic development in this area. However, there are many promising potentials of the island that can be developed although until now because of its limitation, the development of Madura is not yet optimal.

This research used area marketing concept called Strategic Place Triangle model with nine elements that are categorized into three dimensions, namely strategic (segmentation, targeting, positioning), tactic (differentation, marketing mix, and selling), and value (brand name, service, and process). The data that is used in this research is primary data (derived from questionnaries), and secondary data from some related institutions.

The conclusion of the research showed that resourcebased industrial sectors (agricultural and natural industries) are the recommended sectors that shall be developed in Madura area. While the segmentation result showed that there were two main investors, namely PMDN and Non Facility. PMDN investors tend to invest in agriculturalintensive resources and labor intensive (Sumenep and Pamekasan districts), whereas Non Facility investors tend to invest in natural- intensive resorces (Bangkalan and Sampang districts).

Compared to its main competitor, Sidoarjo district, Madura has some added-value, such as inexpensive price of land, investment opportunity, loading and unloading harbor in Bangkalan district, and agricultural and natural resources for industry.
\end{abstract}

Keywords: Development study, Madura Area, Area Marketing, Strategic Place Triangle

\section{INTRODUCTION}

Madura region, an island which consists of four districts (Sumenep, Pamekasan, Sampang, and Bangkalan) is a relatively disadvantaged area compared to other regions in East Java Province. This is reflected in the development indicators which show that the position of the four districts in the Madura region is below other districts in East Java although recent data shows an increase in Pamekasan district. There have been many plans to increase the potential of districts in the Madura region, but these efforts have not been realized thoroughly.

\footnotetext{
1 Muchammad Nurif, Departement of Development Studies, Institut Teknologi Sepuluh Nopember, Surabaya, 60111. E-mail: mnurif69@gmail.com

${ }^{2}$ Hermanto, Departement of Development Studies, Institut Teknologi Sepuluh Nopember, Surabaya, 60111. E-mail: hermantoaku@gmail.com
}

The isolation of the districts in Madura region from other districts or cities in East Java Province by the Madura Strait is one of the factors. In addition, the unavailability of natural conditions in the Madura region for farming activities causes Madurese people tend to migrate to other regions outside Madura island for a better living.

Presidential Decree number 79/2003 concerning the Construction of the Surabaya-Madura Bridge was a new hope for the people in Madura island in their efforts to develop their territory. 2009 was a year of new challenge for residents in the Madura region because the construction of the Surabaya-Madura Bridge project completed. Since then people in Madura island should have begun to improve, including efforts to regain all the potential resources (human and capital) that were outside of the island.

With consideration for accelerating the development of the Surabaya and Madura region by optimizing the existence of the Surabaya-Madura Bridge (Suramadu) as a center for economic development, the government deemed it necessary to change the operation of the Suramadu Bridge from the toll road to a toll free public road. Based on these considerations, in October 26, 2018, President Joko Widodo (Jokowi) signed the Presidential Regulation (Perpres) No. 98/2018 concerning the Surabaya-Madura Bridge stating that the operation of the Surabaya-Madura Bridge has been converted into a public road without tolls.

With the enactment of this Perpres, Presidential Decree Number 79/2003 concerning the Construction of the Surabaya-Madura Bridge and the provisions of Article 12 letter $b$ as amended by Presidential Regulation Number 23/2009 concerning Amendment to Presidential Regulation Number 27/2008 concerning the SurabayaMadura Regional Development Agency, were revoked and declared no longer valid.

Madura island not only stores the potential of salt and tobacco, but also oil and gas. Based on the recent findings, there is quite large potential of natural resources such as oil and natural gas content in Madura and the surrounding islands to develop the Madura region [1].

Efforts to develop districts in Madura must start immediately, especially with the synchronization of development orientation policies among districts in Madura region. Efforts to realize the development synergy among the districts within the Madura region can be valuable capital in efforts to develop this region.

There are at least three approaches in relation to regional development planning, namely the sectoral approach, spatial approach, and the combination of the two approaches. The latest breakthrough is to utilize the concept of regional marketing in the area development 
effort [2] and [3], which has been proven to be effective in developing Yogyakarta province.

The problem that will be examined in this research is the form of the development of Madura which is oriented to regional marketing. The purpose of this study is to obtain a formulation of the development of the Madura area which is oriented towards regional marketing. This study is expected to give advantage on:

a. giving alternatives for the formulation of strategies in developing the Madura region.

b. enriching the knowledge and treasury of science, especially in the application of regional marketing concepts.

\section{RESEARCH METHOD}

The method used in this research is the prescriptive method that refers to the guidelines used in the marketing concept of the "Strategic Place Triangle" area.

In this research, the aspects studied are:

a. The most up-to-date Renstra vision and mission capabilities in each district in Madura in addressing changes in the Madura region.

b. The potential of each regency in Madura as a basis for developing the Madura region.

c. Applying the concept of regional marketing with the Strategic Place Triangle method in an effort to develop the Madura region.

\section{DISCUSSION}

In the Atlas of the Natural Resources of the Madura Coastal Resources [4] the Madura region has four districts, namely Bangkalan, Sampang, Pamekasan, and Sumenep, which are further divided into 68 sub-districts. Geographically Madura island is located at $112^{\circ} 40^{\prime} 06^{\prime \prime}-$ $116^{\circ} 16^{\prime} 48^{\prime \prime}$ east and $4^{\circ} 55^{\prime}-7^{\circ} 31^{\prime}$ south latitude, or is located northeast of Java Island separated by the Madura Strait. The Madura Strait which extends into the boundary forming the island of Madura in the west and south, while the Java Sea becomes the boundary in the east and north.

The area of Madura according to Subaharianto [1] is $5,304 \mathrm{~km}^{2}$, with a length of approximately $190 \mathrm{~km}$ and the widest distance of about $40 \mathrm{~km}$. The area of each regency in the Madura region varies: Bangkalan $1,260 \mathrm{~km}^{2}$, Sampang 1,233 km², Pamekasan $792 \mathrm{~km}^{2}$, and Sumenep $1,989 \mathrm{~km}^{2}$. Located at an altitude between 2-350 meters above sea level. There are 74 small islands and most of them are in the administrative area of Sumenep Regency.

If Java is used as a starting point for departure, then to get to Madura island can be done through two main shipping lines, namely the west which most common or frequent and the east lane. The western route is via Ujung which is a section of the Port of Tanjung Perak, Surabaya in Java island to Kamal which is the port at the western end of Madura island. The eastern path passes through the Anchor Port in Situbondo Regency to Kalianget Harbor, which is at the eastern end of Madura. The eastern path was often used during the Dutch colonial period, especially by residents on Madura island who worked on plantations in the Besuki Residency [5].
The population on Madura island, based on the results of the 2010 Population Census, was 3.1 million people (around 9 percent of East Java's population), spreading in Bangkalan Regency by 907,255 people, Sampang District by 876,950 people, Pamekasan District by 795,526 people, and Sumenep Regency by 1,041,915 people.

\section{A. Marketing}

According to [2] marketing is a social and managerial process by individuals or groups to determine their needs and desires through the creation, supply and exchange of products of value. Marketing management is the process of planning and implementing concepts, prices, promotion and distribution of goods, services, and ideas that can create exchanges with target groups for customer satisfaction and organizational goals or organizational objectives.

There are two groups that become the target in marketing, namely consumers and customers. Consumers are those who consume or use the products produced by a producer. Customers in general can be interpreted by parties who often make purchases or repeat purchases (repeat buying). Basically, customers can also be interpreted by anyone who comes to what we promised ("our promises").

\section{B. Regional Marketing}

According to Kartajaya [3] regional marketing is important, at least as a solution to the three major changes in the macro landscape at the local, national and global levels. At the local level, there is law number 22/1999 concerning Regional Governments and law number 25/1999 concerning Financial Balance between Central and Regional Governments since 2001. These laws underlay a shift in the pattern of government management from "centralized-exploitative oriented" to "participatorydecentralized" oriented.

At the national level, there is a major change in politics after the fall of the New Order government in 1998 which marked a shift in the political system from authoritarianignorant to democratic-accommodative.

At regional-global level, the implementation of AFTA agreement has consequences for various countries to shift their orientation in managing the region from the local orientation to the global-cosmopolitan orientation. This brings effect on the demand that various regions in Indonesia are expected to compete or be aligned with other regions or cities throughout the world.

These various changes cause the government to reorient the management of the regions. At the local level, there must be a change from a bureaucratic-monopolistic government to an entrepreneurial-competitive government. Entrepreneurial government is a government that is observant and always thinks hard in seeing and taking advantage of opportunities to prosper and improve the quality of life of its people. Competitive government is a government that encourages competition among public supervisors in an effort to provide excellent services to their constituents, namely, investors, tourists, and community.

C. Tows Analysis 
TOWS analysis (Threats, Opportunities, Weaknesses, Strengths), is needed after external analysis (technology, economy, politics, culture, market), competitors' conditions, customer behavior, and internal conditions of the region. Furthermore, the components are categorized as threats, opportunities, weaknesses, and regional strengths.

TOWS analysis is conducted because it is an outsidein approach that is identical to market-oriented, and is different from the SWOT approach that is inside-out.

The steps in preparing a TOWS analysis are:

a. Collect various changes in the external environment of competitors, investors, technological changes, political-regulation, socio-cultural, economic, and market.

b. Group them into changes that produce opportunities and changes that pose a threat to the region.

c. Reviewing the internal conditions of the region in terms of resources and competencies.

d. These internal factors are grouped into factors that become strengths and factors that become weaknesses. These strengths and weaknesses are determined relative to the competitors.

To answer the problem in the effort to develop the Madura region, efforts were made to apply regional marketing using the Strategic Place Triangle concept as the latest regional marketing concept.

\section{Review of Vision and Mission in The District Strategic Plan Document in The Madura Area}

Review was conducted to four districts' strategic plan documents in the Madura region, namely review of Bangkalan Regency strategic plan 2013-2018, review of Sampang Regency strategic plan 2013-2018, review of Pamekasan Regency strategic plan 2013-2018, and review of Sumenep Regency strategic plan 2013-2018.

All documents were compiled based on internal conditions/facts in each district. Even though efforts to accelerate the development of the Madura region are prioritized, it is necessary to accommodate every aspect of the challenges and opportunities that will be faced.

\section{E. Review of Vision and Mission in The Bangkalan District Strategic Plan 2013-2018}

The vision of the RPJMD which is the vision of the Head of the Region must be in line with the long-term vision of Bangkalan Regency, as contained in the Bangkalan Regency RPJPD 2005 - 2025 namely: "Bangkalan As A Strong Industrial, Trade, And Service District To The Create Madani Community" [6]

Referring to the Bangkalan Regency RPJPD, the formulation of the vision of Bangkalan Regency RPJMD Year 2013 - 2018 is: "Bangkalan As Prospeous, Independent, And Religious"

\section{F. Review of Vision and Mission in The Sampang District Strategic Plan 2013-2018}

The vision of the Regional Head and Deputy Regional Head to be achieved in the period of the Sampang Regency Medium-Term Development Plan (RPJMD) for 2013-
2018 is "Creating a Healthy Bureaucracy, Strong Communities and Friendly Environments, for the achievement of the Dignified Sampang District" [7]

The mission of Sampang Regency is as follows: 1. Realizing good and professional governance, 2. Improving quality and affordable services, 3 . Maximizing the use of regional potential in accordance with the capacity of the Environment. 4. Enhancing quality economic growth. 5. Increasing community participation in government administration and development.

\section{G. Review of Vision and Mission in The Pamekasan Regency Strategic Plan 2013-2018}

Considering the potential, conditions and problems that exist in Pamekasan Regency, the Pamekasan Regency Vision to be achieved in 2013-2018 is: "The realization of a clean, healthy, smart, and prosperous Pamekasan based on faith and piety supported by professional apparatus ". [8]

In the effort to realize the vision of development in Pamekasan Regency in 2013-2018, the Pamekasan Regency development missions are as follows: a) Expanding education and equalizing the quality of education based on regional potential; b) Improving and optimizing health care facilities through improving health facilities; c) Speeding up the development of public infrastructure; d) Promoting economic development with priorities in the agricultural sector and optimization of regional leading commodities with environmental insight; e) Accelerating bureaucratic reform in all fields, and good governance (transparent and accountable); f) Increasing the convenience of public services that are fast, simple and inexpensive.

\section{H. Review of Vision and Mission in The Sumenep Regency Strategic Plan 2013-2018}

The vision of the Sumenep Regency as listed in the Sumenep Regency Medium Term Regional Development Plan (RPJMD) is: "Sumenep is More Prosperous with an Independent, Religious, Nationalist, Transparent, Fair and Professional Government". [9]

By referring to the Vision of the elected Regional Head and Deputy Regional Head and Sumenep's RPJPD document for 2010 - 2025 that becomes a guide in the preparation of the RPJMD for elected Regional Heads 2016-2021, the mission and priority programs of the Sumenep Regency are then elaborated as follows: 1) Improving the quality of human resources through education, health and poverty alleviation; 2) Accelerating the development of island and land area infrastructure supported by sustainable management of natural resources and the environment; 3 ) Increasing the independence of rural and urban economies by empowering the potential of a superior and highly competitive local economy; 4) Enhancing professional and accountable culture and governance; 5) Improving governance in safe and conducive community life through community and stakeholders participation in the development process; 6) Enhancing religious and cultural values and nationalism supported by local wisdom in social life; 


\section{Tows Analysis}

Based on the exposure from external and internal analysis in the previous discussion, the following analysis can be carried out:

a. Threat

There are at least three things that pose a threat to the development of the Madura region in the future. First, is the relatively higher level of information technology advances, access, and mastery of information technology by people outside the Madura region. Second, the intense competition between regions in the era of regional autonomy, in which some regions have already applied the principles of regional autonomy in marketing their regions. Third, the readiness of the local government, especially in dealing with forms of urban problems due to the existence of the Suramadu bridge.

\section{c. Weakness}

The main weakness owned by the people in the Madura region is the low quality of human resources, whereas in regional marketing competition, the qualified human resources plays an important role. Second is the high flow of migration to outside the Madura region. Third is the isolation of the Madura region for a long time making this area unattractive to investors.

\section{d. Strength}

b. Opportunity

Opportunities in developing the Madura region are first, the existence of information technology can facilitate the marketing of the untapped potentials in the Madura region. Second, regional autonomy can be the basis for structuring regions in the Madura region according to regional needs. Third, the existence of the Suramadu bridge eliminates transportation obstacles and that will smoothen the flow of products/commodities/people from and to the Madura region.

\section{K. Brand Positioning - Differentiation}

The main competitor for industrial development in the Madura region is Sidoarjo Regency. Some factors that make the Madura area more attractive for industrial development in the future are:

a. The land needed for industry is cheaper than land in Sidoarjo Regency.

b. Investment opportunities are large enough, especially as a result of the construction of the Suramadu bridge.

c. Having its own loading and unloading port in Bangkalan Regency as an expansion of the Tanjung Perak Port of Surabaya.

d. Natural resources and agriculture are still possible to be developed.

The brand chosen to represent the Madura region should be something that shows the unique identity of the Madura region (both the community and the region) and is a promise especially to investors who will invest in industries in the Madura region.

Efforts to socialize the brand for the Madura region are attempted through labeling on products produced by industries in the Madura region. In addition, the brand
The main strength possessed by the Madura region is the character of Madurese who have high self-esteem that can be the spirit of developing Madura in the future. Second, the Madura area is very close to Surabaya city which is the main trade center in East Java Province and close to the largest market potential that is population of East Java Provence. Third, the quite large distribution of diverse and still unexploited potential of natural resources gives hope in attracting investors to the Madura region.

\section{J. Formulating The Vision}

Based on the description in the previous section, the development of the Madura region will be focused on the industrial sector especially resource-intensive industries, which are expected to create jobs for the people of the Madura region and thus the welfare of the Madurese community will be realized. The strong spirit or character possessed by the Madurese community can be used as the main capital or spirit in the development of the Madura region. The development of the Madura region is expected to only take ten years, in which the first two years are critical periods mainly because at that time it was an initial acceleration process of preparing the Madura community before the Suramadu bridge was realized. Thus the vision of the Madura region is: "Madurese Community Towards Madani Industrial Community 2025"

also needs to be socialized to the community, with the hope that real implementation will be realized down to earth and gives pride to the community.

\section{CONCLUSION}

The development of the Madura area which is oriented towards regional marketing recommends the industrial sector having the potential to be developed in the Madura region in the future.

The results of segmentation show that business customers or investors in the Madura region can be divided into two groups, namely domestic or PMDN investors $(63.35 \%)$ and Non Facilities (36.44\%). PMDN investors tend to invest in types of industries that are agricultural and labor intensive. While NonFacility investors tend to choose natural resourceintensive industries. Most PMDN investors invest in Sumenep and Pamekasan Regencies, while Non Facility Investors invest in Bangkalan and Sampang Regencies.

PMDN investors are the main target of business customers in the Madura region because on average it absorbs a lot of labor (an average of 29 workers) and its industrial products are agricultural resource intensive (such as fish processing, tobacco, and salt) and labor intensive (boat making). Non-Facility Investors are the next target, whose industries are generally natural resource-intensive (tile and phosphate manufacture).

The main competitor faced by the Madura region is Sidoarjo Regency. However, the Madura region has major advantages for investment compared to its competitors, namely relatively low land prices, investment opportunities that are open as a result of the construction of the Suramadu bridge, having a loading 
and unloading port in Bangkalan Regency, as well as potential agricultural and natural resources to develop for industry.

\section{SUGGESTION}

The need to follow up the results of this study with a study on the efforts to develop the Madura region viewed from an institutional approach.

\section{REFERENCES}

[1] A. dkk. Subaharianto, Tantangan Industrialisasi Madura: Membentur Kultur, Menjunjung Leluhur. Malang: Bayumedia Publishing, Malang, 2004.

[2] P. dkk. Kotler, Rethinking Market-ing Sustainable Enterprise di Asia. (Terjemahan). Jakarta: PT Prenhallindo, Jakarta, 2003.

[3] H. dkk. Kartajaya, Attracting, Tourists, Traders, Investors: Strategi Memasarkan Daerah di Era Otonomi. Jakarta: MarkPlus \& Co, Jakarta, 2005.

[4] Bappeprop Jawa Timur, Rencana Tata Ruang Wilayah (RTRW) Propinsi Jawa Timur. Surabaya: Bappeprop, 2008.

[5] N. D. Riant, Reinventing Pembangunan: Menata Ulang Paradigma Pembangunan untuk Membangun Indonesia Baru dengan Keunggulan Global. Jakarta: Elex Media Komputindo, Jakarta, 2003.

[6] Pemkab Bangkalan, Review Visi dan Misi dalam Renstra Kabupaten Bangkalan 2013-2018. Bangkalan: Pemkab Bangkalan, 2013.

[7] Pemkab Sampang, Review Visi dan Misi dalam Renstra Kabupaten Sampang 2013-2018. Sampang: Pemkab Sampang, 2013.

[8] Pemkab Pamekasan, Review Visi dan Misi dalam Renstra Kabupaten Pamekasan 2013-2018. Pamekasan: Pemkab Pamekasan, 2013.

[9] Pemkab Sumenep, Review Visi dan Misi dalam Renstra Kabupaten Sumenep 2013-2018. Sumenep: Pemkab Sumenep, 2013. 
TABLE 1

TOWS MATRIX

\begin{tabular}{|c|c|c|}
\hline $\begin{array}{l}\mathbf{I} \\
\mathbf{N} \\
\mathbf{T} \\
\mathbf{E} \\
\mathbf{R} \\
\mathbf{N} \\
\mathbf{A} \\
\mathbf{L}\end{array}$ & $\begin{array}{l}\text { STRENGTHS (S) } \\
\text { - Madurese who has high self-esteem } \\
\text { character. } \\
\text { - Position adjacent to the Surabaya trade } \\
\text { center. } \\
\text { - Strategic areas with the greatest market } \\
\text { potential (East Java residents). } \\
\text { Distribution of various and potential } \\
\text { natural resources to be developed. }\end{array}$ & $\begin{array}{l}\text { WEAKNESSES (W) } \\
\text { - Human resources in the Madura region } \\
\text { are still low. } \\
\text { The migration flow of most people to } \\
\text { outside the Madura region. } \\
\text { - The isolation of the Madura region makes } \\
\text { it unattractive to investors. }\end{array}$ \\
\hline \multicolumn{3}{|l|}{ EXTER N A L } \\
\hline $\begin{array}{l}\text { OPPORTUNITIES (O) } \\
\text { - Information technology facilitates in } \\
\text { marketing of industrial potential in the } \\
\text { Madura region. } \\
\text { - Regional autonomy can be the basis for } \\
\text { structuring the Madura region. } \\
\text { Within the same Regional Coordination } \\
\text { Board (Bakorwil) with Regency/City } \\
\text { whose economy is fast. } \\
\text { The Suramadu Bridge smoothen the } \\
\text { flow of products to and from the } \\
\text { Madura region. }\end{array}$ & $\begin{array}{l}\text { STRATEGY (SO) } \\
\text { - Formulating human resource } \\
\text { development policies. } \\
\text { Developing natural resource-based } \\
\text { industries with the highest economic } \\
\text { final output. } \\
\text { Optimizing the development of market- } \\
\text { oriented products, especially local and } \\
\text { the main target market, namely the } \\
\text { population of East Java. } \\
\text { Recommending the Regional } \\
\text { Coordination Board's (Bakorwil) role, } \\
\text { not just coordination but facilitation of } \\
\text { accelerating regional development. } \\
\text { STRATEGY (ST) } \\
\text { Making strong community character } \\
\text { become the capital of regional } \\
\text { resilience and can be directed to } \\
\text { develop the regions } \\
\text { Increasing the density of technological } \\
\text { mastery of Madurese society. } \\
\text { Building cooperation with trade } \\
\text { stakeholders in the city of Surabaya in } \\
\text { marketing products from Madura. }\end{array}$ & $\begin{array}{l}\text { STRATEGY (WO) } \\
\text { - Utilizing information technology to } \\
\text { introduce the potential of the Madura } \\
\text { region. } \\
\text { Making Madurese people outside the } \\
\text { region as a means of introducing Madura. } \\
\text { - Making synergistic investment policies } \\
\text { between regions and facilitating } \\
\text { investment licensing } \\
\text { - Improving transportation infrastructure } \\
\text { connecting Suramadu bridge to the } \\
\text { regions in Madura } \\
\text { STRATEGY (WT) } \\
\text { - Optimizing the mastery of information } \\
\text { technology in society. } \\
\text { Trying to attract potential Madurese } \\
\text { people outside of areas. } \\
\text { Preparing bureaucrats and the public, } \\
\text { especially in responding to the existence } \\
\text { of the Suramadu bridge }\end{array}$ \\
\hline
\end{tabular}

